\title{
A stable peroxovanadium compound with insulin-like action in human fat cells
}

\author{
J.W. Eriksson ${ }^{1}$, P. Lönnroth ${ }^{1}$, B. I. Posner ${ }^{2}$, A. Shaver ${ }^{3}$, C. Wesslau ${ }^{1}$, U.P. G. Smith ${ }^{1}$ \\ ${ }^{1}$ Lundberg Laboratory for Diabetes Research, Department of Internal Medicine, Sahlgrenska University Hospital, Göteborg \\ University, Göteborg, Sweden \\ ${ }^{2}$ Department of Medicine, McGill University, The Royal Victoria Hospital, Montreal, Canada \\ ${ }^{3}$ Department of Chemistry, McGill University, The Royal Victoria Hospital, Montreal, Canada
}

Summary Aqueous solutions of peroxovanadium $(\mathrm{pV})$ compounds are potent insulin-mimics in various types of cell. Since chemical instability is a problem with these agents, we studied the insulin-like action in human fat cells of a stable $\mathrm{pV}$ complex, bpV(pic). It enhanced ${ }^{14} \mathrm{C}$-U-glucose uptake in a dose-dependent manner by approximately twofold which was slightly less than the effect of insulin (approximately threefold). The $\mathrm{pV}$ complex did not alter cell-surface insulin binding and submaximal concentrations did not influence cellular sensitivity to insulin action on glucose uptake. The bpV(pic) inhibited the lipolytic effect of isoprenaline to the same extent as insulin; however, when the cGMP-inhibitable low- $\mathrm{K}_{\mathrm{m}}$ phosphodiesterase (cGI-PDE) was blocked with the specific inhibitor OPC 3911, the antilipolytic effect of insulin, but not that of bpV(pic), was completely prevented. Moreover, when lipolysis was stimulated by the non-hydrolysable cAMP analogue $\mathrm{N}^{6}$-monobutyryl cAMP, bpV(pic), in contrast to insulin, main- tained an antilipolytic effect. These findings indicate that $b p V(p i c)$ exerts its antilipolytic effect not only through cGI-PDE activation, similar to the effect of insulin, but also by means of other mechanisms. The tyrosine kinase activity of insulin receptors from human placenta was not altered by the $\mathrm{pV}$ compound itself, whereas bpV(pic) clearly enhanced insulin-stimulated activity. In contrast, in situ tyrosine phosphorylation of the insulin receptor $\beta$-subunit as well as that of several other proteins was clearly increased in cells which were treated with bpV(pic), whereas vanadate only amplified insulin-stimulated tyrosine phosphorylation. In conclusion, bpV(pic) exerts powerful insulin-like effects in human fat cells and may be a new and potentially useful agent in the management of insulin-resistant states. [Diabetologia (1996) 39: 235-242]

Key words Adipocytes, insulin, vanadate, peroxovanadate, glucose uptake, lipolysis, tyrosine kinase.
Vanadium is a trace element which is essential for most plant and animal species [1]; it is found in small amounts in various tissues [2]. Vanadium salts, e.g. vanadyl sulphate, sodium metavanadate or orthovanadate are well-known insulin-mimics [3]; this has been shown in cellular studies in vitro for glucose up-

Received: 12 June 1995 and in revised form: 15 September 1995

Corresponding author: Dr. I. Eriksson, Department of Internal Medicine, Sahlgren's Hospital, S-413 45 Göteborg, Sweden Abbreviations: pV, Peroxovanadium; bpV(pic), potassium bisperoxopicolinatooxovanadate; cGI-PDE, cGMP-inhibitable low- $\mathrm{k}_{\mathrm{m}}$ phosphodiesterase; $\mathrm{EC}_{50}$, half-maximal concentration; PTP, phosphotyrosine phosphatase; sp act, specific activity; WGA, wheat-germ agglutinin. take and metabolism, antilipolysis and glycogen synthase activation [3-6]. Moreover, the insulin-like action of vanadate has also been demonstrated in vivo, and studies have shown that vanadate treatment improves glucose homeostasis in diabetic rats [7, 8]. One possible mechanism involved may be the ability of vanadate to enhance insulin receptor tyrosine kinase activity $[6,9]$ which, in turn, is attributed to phosphotyrosine phosphatase (PTP) inhibition [10]. However, other studies suggest that at least some of the insulin-like effects of vanadate occur independently of the tyrosine kinase $[5,11]$.

Hydrogen peroxide $\left(\mathrm{H}_{2} \mathrm{O}_{2}\right)$ can exert insulin-like effects [12] and since intracellular $\mathrm{H}_{2} \mathrm{O}_{2}$ production is enhanced by insulin it has been proposed as a 
second messenger in insulin signalling $[13,14]$. An aqueous solution of hydrogen peroxide and vanadate generates peroxovanadates $(\mathrm{pV})$, which are more potent as insulin-mimics than either agent by itself [15, 16]. $\mathrm{pV}$ compounds are far more potent PTP inhibitors than vanadate, and, as a consequence, can enhance insulin receptor tyrosine kinase activity [1518]. We recently reported that $\mathrm{pV}$ solutions, but not vanadate, display insulinomimetic properties in human adipocytes [19]. This is in contrast to rat adipocytes where both agents are effective $[15,16]$. Thus, $\mathrm{pV}$ is potentially interesting for the treatment of insulin-resistant states in humans. However, one problem with aqueous $\mathrm{pV}$ solutions is their chemical instability [15]. Therefore, the insulin-like action in human fat cells of a well-characterized stable $\mathrm{pV}$ compound, potassium bisperoxopicolinatooxovanadate, bpV (pic) [18], was investigated.

\section{Subjects, materials and methods}

Materials. Human monocomponent insulin and mono $\left[{ }^{125} \mathrm{I}\right]$ tyr$\mathrm{A}_{14}$-insulin (specific activity [sp act] $200-300 \mu \mathrm{Ci} / \mu \mathrm{g}$ ) were purchased from Novo (Copenhagen, Denmark). $\left[{ }^{14} \mathrm{C}\right] \mathrm{U}-\mathrm{D}$-glucose (sp act $246 \mu \mathrm{Ci} / \mu \mathrm{mol}$ ) and ECL chemiluminescence kit were from Amersham (Amersham, Bucks, UK) and $\left[\gamma^{32} \mathrm{P}\right]$ ATP (sp act $3 \mathrm{Ci} / \mu \mathrm{mol}$ ) was from Du Pont (Geneva, Switzerland). Collagenase, bovine serum albumin (fraction V), wheat-germ agglutinin (WGA), isoprenaline, $\mathrm{N}^{6}$-monobutyryl cAMP, Glu $^{80}-\mathrm{Tyr}^{20}$, Ro-1724 and protease inhibitors were from Sigma (St. Louis, Mo., USA). The OPC 3911 was a kind gift from Dr. P. Belfrage (Lund, Sweden). Medium 199 was obtained from Statens Bakteriologiska Laboratorium (Stockholm, Sweden) and sodium orthovanadate $\left(\mathrm{Na}_{3} \mathrm{VO}_{4}\right)$ from $\mathrm{BDH}$ Chemicals (Poole, Dorset, UK). A monoclonal mouse antiphosphotyrosine antibody was purchased from UBI (Lake Placid, N.Y., USA). The bpV(pic) was synthesized and purified as described previously [18] by Dr. J. Ng, Department of Chemistry, McGill University (Montreal, Canada).

Adipose tissue biopsies. Biopsies ( $3-5 \mathrm{~g}$ ) of subcutaneous adipose tissue were removed from non-diabetic subjects $(n=22)$ undergoing elective abdominal surgery for non-malignant disease. The biopsies were obtained immediately after induction of anaesthesia and placed in a vessel containing medium 199 at $37^{\circ} \mathrm{C}$. The study was approved by the ethics committee of Göteborg University.

Isolation of adipose cells. Dissected tissue pieces ( $\sim 5 \mathrm{mg}$ ) were incubated at $37^{\circ} \mathrm{C}$ in medium 199 containing $4 \%$ bovine serum albumin and $0.8 \mathrm{mg} / \mathrm{ml}$ collagenase in a shaking water bath. After approximately $50 \mathrm{~min}$, liberated cells were filtered through a nylon mesh and washed 4 times in fresh medium containing albumin. Cell size and number were measured as described previously [20]. The average fat cell volume was $0.53 \pm 0.04 \mathrm{nl} /$ cell (mean $\pm S E M$, calculated from the average cell volume of each of the 22 patients).

${ }^{14} \mathrm{C}$ - $U$-glucose uptake. Cellular uptake of ${ }^{14} \mathrm{C}$-U-glucose was measured during a $1-\mathrm{h}$ incubation of cells at $37^{\circ} \mathrm{C}$ in glucosefree medium 199 at a lipocrit of 3-5\%. Following pre-incubation for $15 \mathrm{~min}$ in the absence or presence of insulin, bpV(pic) and other agents as indicated, $0.86 \mu \mathrm{mol} / \mathrm{I}^{14} \mathrm{C}-\mathrm{U}$-glucose was added. After $1 \mathrm{~h}$ the cells were separated from the incubation medium, put into scintillation fluid and radioactivity was counted. The cellular clearance of medium glucose was calculated according to the formula:

$\frac{(\mathrm{cpm} \text { cells })}{(\mathrm{cpm} \text { medium }) \times(\text { cell number }) \times \mathrm{s}}$

and taken as an index of the rate of glucose uptake [21]. Cellassociated radioactivity obtained when the tracer was added immediately before separation from medium was subtracted to correct for extracellularly trapped radioactivity $(9.1 \pm 1.0 \%$ of total radioactivity in non-stimulated cells).

Lipolysis. Isolated cells at a lipocrit of $1-3 \%$ were incubated at $37^{\circ} \mathrm{C}$ with or without isoprenaline, insulin or bpV(pic) at the indicated concentrations for $1 \mathrm{~h}$. The incubation was stopped by centrifuging the cells through silicone oil. The glycerol content of the incubation medium was analysed [22] and taken as an index of lipolysis.

Partial purification of insulin receptors from human placenta. Human placental membranes were obtained essentially as previously reported [23] and were solubilized in $1 \%$ Triton X-100. Following centrifugation at $9,000 \times g$ for $10 \mathrm{~min}$, the supernatant was applied to a WGA agarose column and allowed to recirculate 3 times [24]. After careful washing, the purified insulin receptors were eluted with $0.3 \mathrm{~mol} / 1 \mathrm{~N}$-acetylglucosamine in 4-(2-hydroxyethyl)-1-piperazine ethane sulphonic acid (Hepes) buffer. Insulin binding was determined by adding $0.034 \mathrm{pmol}{ }^{125} \mathrm{I}$-insulin to $100 \mu \mathrm{l}$ eluate. After $18 \mathrm{~h}$ at $4^{\circ} \mathrm{C}$, the receptors were precipitated with polyethyleneglycol using $\operatorname{IgG}$ as a carrier and specific binding was measured.

Insulin receptor tyrosine kinase activity. Triplicate samples $(40 \mu \mathrm{l})$ of the eluate containing purified insulin receptors were incubated for $15 \mathrm{~min}$ at $20^{\circ} \mathrm{C}$ with $2 \mathrm{mmol} / 1 \mathrm{MnCl}_{2}$ in the presence or absence of $\mathrm{bpV}(\mathrm{pic})$, vanadate and insulin as indicated. Unlabelled ATP $(15 \mu \mathrm{mol} / \mathrm{l})$ was then added and after an additional $15 \mathrm{~min} \mathrm{Glu}^{80}-\mathrm{Tyr}^{20}(2.5 \mathrm{mg} / \mathrm{ml})$ together with [ $\left.{ }^{32} \mathrm{P}\right]$ ATP $\left(-10^{6} \mathrm{cpm}\right.$ ) plus unlabelled ATP (maintaining the total ATP concentration at $15 \mu \mathrm{mol} / 1$ ) were added to a final volume of $100 \mu \mathrm{l}$. The incubations were then continued for another 15 min. Aliquots $(75 \mu \mathrm{l})$ were spotted on Whatman 3-MM papers (Whatman International, Maidstone, Kent, UK), washed with $10 \%$ trichloroacetic acid containing $10 \mathrm{mmol} / 1 \mathrm{Na}_{4} \mathrm{P}_{2} \mathrm{O}_{7}$ and then once with $95 \%$ ethanol followed by $95 \%$ acetone. Radioactivity was determined by scintillation counting, and the background obtained from samples without $\mathrm{Glu}^{80}-\mathrm{Tyr}^{20}$ was subtracted.

Detection of phosphotyrosine-containing proteins in whole cell lysates by immunoblotting. Adipose cells were pre-incubated for $5 \mathrm{~min}$ at $37^{\circ} \mathrm{C}$ in medium 199 in the presence or absence of $b p V(p i c)$ and vanadate as indicated and the incubation was then continued for another $10 \mathrm{~min}$ with or without addition of insulin $(1000 \mu \mathrm{U} / \mathrm{ml})$. Then, $400 \mu \mathrm{l}$ of cells per sample were centrifuged through dinonylphthalate and were lysed with $0.4 \mathrm{ml}$ of a solution (Lysis Medium) containing (in mmol/1) 25 Tris- $\mathrm{HCl}, \mathrm{pH} 7.4,0.5 \mathrm{EGTA}, 25 \mathrm{NaCl}, 1$ sodium orthovanadate, $10 \mathrm{NaF}, 0.2$ leupeptin, 1 benzamidine, and 0.1 4-(2Aminoethyl)-benzene sulphonylfluoride (Calbiochem, La JolIa, Calif., USA) $1 \%$ NP-40 and rocked for $40 \mathrm{~min}$ at $4^{\circ} \mathrm{C}$. The solubilized proteins were separated on a $10 \%$ SDS-polyacrylamide gel, transferred to a nitrocellulose membrane, and immunoblotted with monclonal anti-phosphotyrosine antibody according to the recommendations of the manufacturer. An ECL chemiluminescence kit with a secondary, horseradish- 


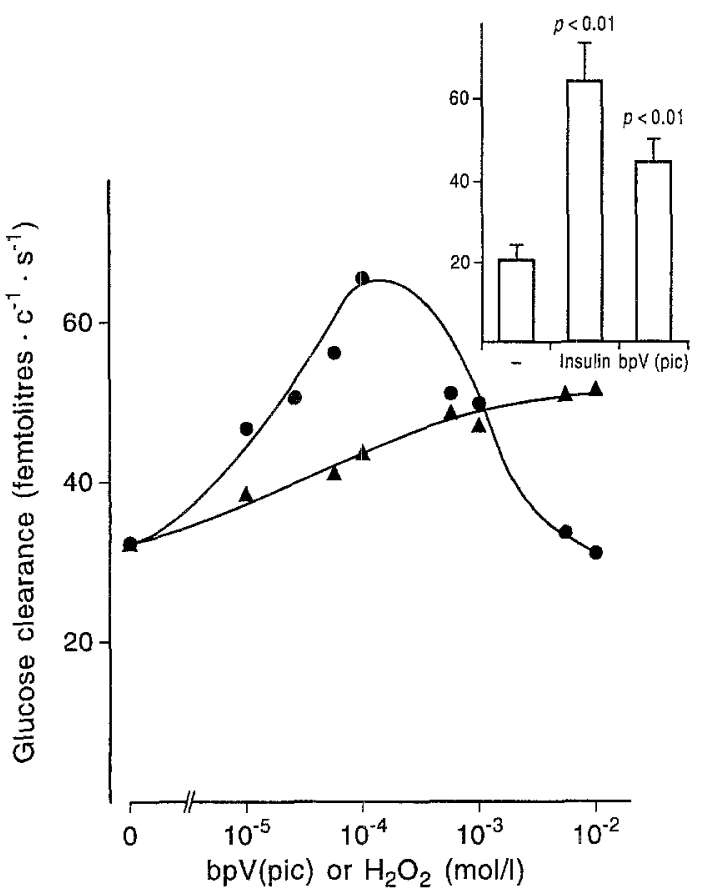

Fig. 1. Effect of bpV(pic) (O) and $\mathrm{H}_{2} \mathrm{O}_{2}(\boldsymbol{\Delta})$ on glucose uptake in human adipocytes. Cells were incubated for $15 \mathrm{~min}$ at $37^{\circ} \mathrm{C}$ with the indicated concentrations of $\mathrm{bpV}\left(\right.$ pic) or $\mathrm{H}_{2} \mathrm{O}_{2}$ after which ${ }^{14} \mathrm{C}$-U-glucose was added. After $60 \mathrm{~min}$ cell-associated and total medium radioactivity was measured. Data are from one representative experiment of three. Insert: Effects of insulin and $\mathrm{bpV}(\mathrm{pic})$. Cells were pre-incubated for $15 \mathrm{~min}$ at $37^{\circ} \mathrm{C}$ with or without $1000 \mu \mathrm{U} / \mathrm{ml}$ insulin and $0.1 \mathrm{mmol} / \mathrm{l}$ $\mathrm{bpV}$ (pic), respectively. Data are means \pm SEM of six separate experiments

peroxidase-labelled antibody (Amersham), was employed and the bands were visualized on an autoradiography film.

\section{Statistical analysis}

Unless otherwise indicated, statistical significance of differences was tested with Student's two-tailed $t$-test for paired observations. Data are expressed as means $\pm \mathrm{SEM}$.

\section{Results}

${ }^{14} \mathrm{C}$ - $U$-glucose uptake. The compound bpV(pic) stimulated ${ }^{14} \mathrm{C}$-U-glucose uptake in human adipocytes in a dose-dependent manner. The maximum effect was approximately twofold and occurred at a $\mathrm{bpV}(\mathrm{pic})$ concentration of approximately $0.1 \mathrm{mmol} / 1$ (Fig. 1). The effect of insulin was somewhat more pronounced $(p<0.05)$ with an approximately threefold increase in glucose uptake (Fig. 1, insert). The dose-response curve for $\mathrm{bpV}($ pic) was bell-shaped with a complete return to basal glucose uptake at very high concentrations (Fig. 1). However, the range of effective concentrations covered at least three orders of magnitude. The $\mathrm{EC}_{50}$ (concentration producing half-maximal effect) for $\mathrm{bpV}(\mathrm{pic})$ was $0.026 \pm 0.006 \mathrm{mmol} / \mathrm{l}(n=6)$.

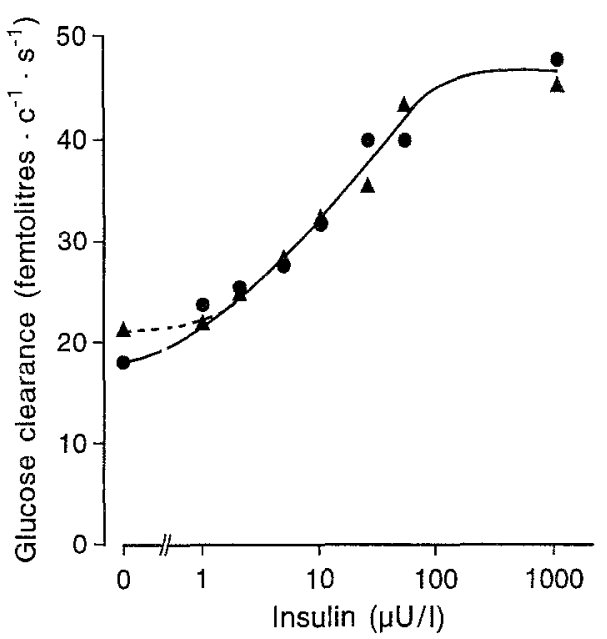

Fig. 2. Effect of insulin on glucose uptake in the presence $(\boldsymbol{A})$ or absence ( $)$ of $0.005 \mathrm{mmol} / \mathrm{lbpV}$ (pic). Cells were pre-incubated with the indicated concentrations of insulin and glucose uptake was measured as in Figure 1. Data are from one representative experiment of three

For comparison, the effect of $\mathrm{H}_{2} \mathrm{O}_{2}$ alone was also studied. The maximal effect of this agent was smaller $(n=3, p<0.05)$ than that of $\mathrm{pV}(-50 \%$ increase in ${ }^{14} \mathrm{C}$-U-glucose uptake) and required a much higher concentration, approximately $10 \mathrm{mmol} / 1$ (Fig.1). Above this concentration, there was no additional effect of $\mathrm{H}_{2} \mathrm{O}_{2}$ (data not shown).

Next, the possible effects of $\mathrm{bpV}($ pic) on insulin sensitivity were studied. Submaximal concentrations ( 0.005 and $0.01 \mathrm{mmol} / \mathrm{l}$, respectively) of $\mathrm{bpV}(\mathrm{pic}) \mathrm{ad}-$ ded together with insulin at various concentrations did not affect the dose-response curve for insulin (Fig. 2). Only at very low insulin concentrations, was the intrinsic effect of $\mathrm{bpV}(\mathrm{pic})$ demonstrable. At higher insulin concentrations the effect of $b p V(p i c)$ was negligible and insulin sensitivity was unaffected (Fig.2). Furthermore, no additive or inhibitory effects were seen when high concentrations of insulin $(1000 \mu \mathrm{U} / \mathrm{ml})$ and $\mathrm{bpV}(\mathrm{pic})(0.1 \mathrm{mmol} / \mathrm{l})$ were combined (data not shown).

Sodium orthovanadate at several different concentrations (from 0.5 to $8 \mathrm{mmol} / \mathrm{l}$ ) did not exert any effect on glucose uptake (data not shown). However, when added together with $\mathrm{bpV}(\mathrm{pic})$, an inhibitory interaction was seen. Vanadate decreased $b p V($ pic)stimulated glucose uptake in a dose-dependent manner (Fig.3). In contrast, no such inhibition was exerted by vanadate when combined with insulin (data not shown).

Preincubating cells with $\mathrm{bpV}$ (pic) for $20 \mathrm{~min}$ at different concentrations $(0.01-0.5 \mathrm{mmol} / \mathrm{l}) \mathrm{did}$ not produce any change in subsequent cell surface ${ }^{125}$ I-insulin binding (performed at $16^{\circ} \mathrm{C}$ in the presence of $\mathrm{KCN}$ as described previously [25]) (data not shown). Neither was ${ }^{125} \mathrm{I}$-insulin binding at $37^{\circ} \mathrm{C}$ for $1 \mathrm{~h}$ altered by the concomitant presence of $\mathrm{bpV}$ (pic) (data not shown). 


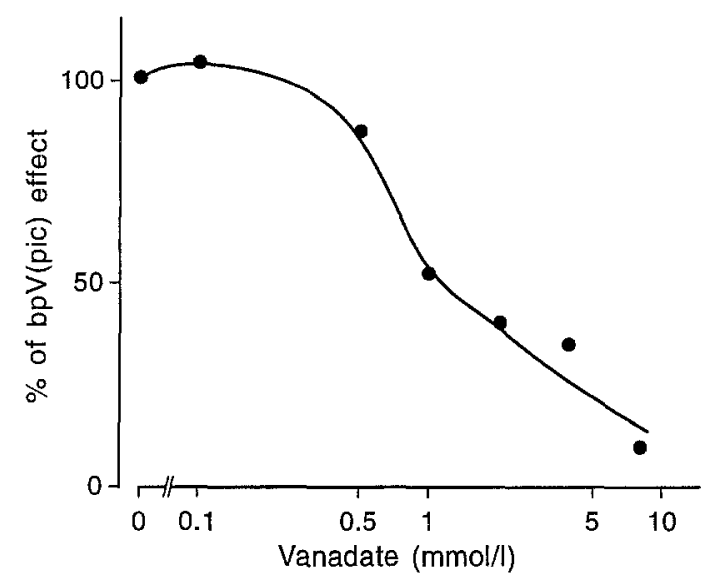

Fig. 3. Effect of vanadate on $b p V(p i c)$-stimulated glucose uptake. Cells were pre-incubated with $0.1 \mathrm{mmol} / 1 \mathrm{bpV}$ (pic) together with the indicated concentrations of sodium orthovanadate. Data are from one representative experiment of three and are expressed as percent of maximal increase (produced by bpV(pic) alone)
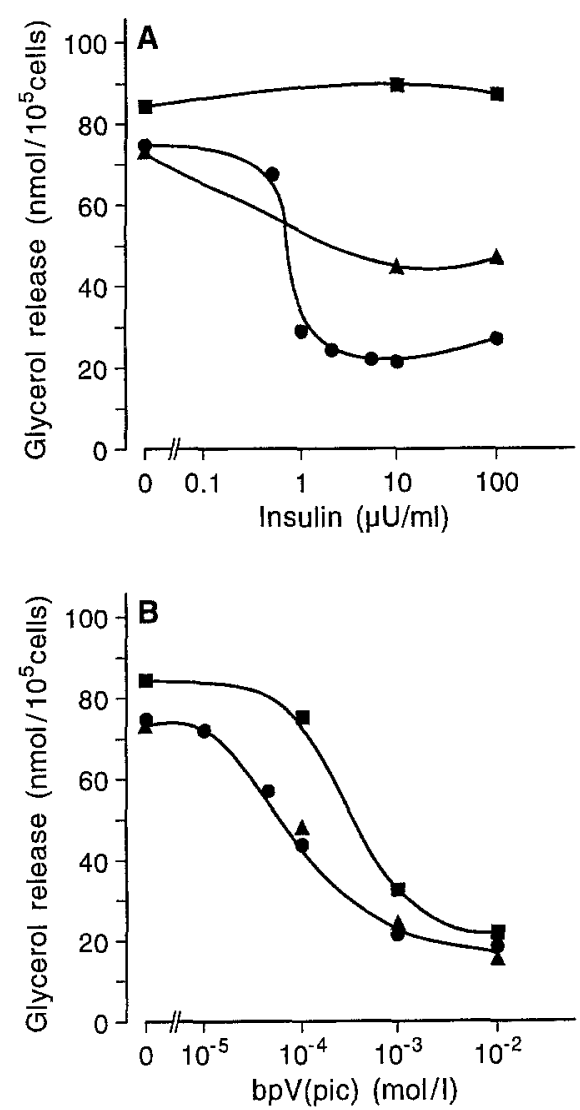

Fig.4. Antilipolytic effect of insulin (A) and $b p V(p i c)(B)$. Cells were incubated for $60 \mathrm{~min}$ with isoprenaline $(1 \mu \mathrm{mol} / 1)$ and insulin or $\mathrm{bpV}(\mathrm{pic})$ at the indicated concentrations in the absence (O) or presence of OPC $3911(10 \mu \mathrm{mol} / \mathrm{l}, \square)$ or Ro1724 ( $50 \mu \mathrm{mol} / 1, \mathbf{A})$. Then, glycerol release was assessed. Data are from one representative experiment repeated 4 times
Table 1. Tyrosine kinase activity of WGA-purified insulin receptors from human placenta - effects of insulin, bpV(pic) and vanadate

\begin{tabular}{lllll}
\hline Insulin & - & $\begin{array}{l}\mathrm{bpV}(\mathrm{pic}) \\
(0.05 \mathrm{mmol} / \mathrm{l}) \\
\text { Activity }\end{array}$ & $\begin{array}{l}\mathrm{bpV}(\mathrm{pic}) \\
(0.5 \mathrm{mmol} / \mathrm{l}) \\
(\% \text { of basal })\end{array}$ & $\begin{array}{l}\text { Vanadate } \\
(1 \mathrm{mmol} / \mathrm{l})\end{array}$ \\
\hline- & 100 & $109 \pm 10$ & $127 \pm 19$ & $121 \pm 13$ \\
$10^{3} \mu \mathrm{U} / \mathrm{ml} l$ & $204 \pm 32^{\mathrm{b}}$ & $261 \pm 47^{\mathrm{bc}}$ & $389 \pm 68^{\mathrm{ac}}$ & $248 \pm 74^{\mathrm{a}}$ \\
$10^{5} \mu \mathrm{U} / \mathrm{ml}$ & $240 \pm 38^{\mathrm{b}}$ & $300 \pm 63^{\mathrm{ac}}$ & $479 \pm 73^{\mathrm{ac}}$ & $\mathrm{ND}$ \\
\hline
\end{tabular}

Samples of eluate from WGA-columns were incubated at $20^{\circ} \mathrm{C}$ with insulin and other agents as indicated for $15 \mathrm{~min}$ followed by the addition of ATP and then, after another $15 \mathrm{~min}$, addition of ${ }^{32}$ P-ATP (total ATP concentration $15 \mu \mathrm{mol} / 1$ ) and $\mathrm{Glu}^{80}-\mathrm{Tyr}^{20}$ (see Materials and Methods). Activity is expressed as percent of non-stimulated activity and was assessed as phosphate incorporation in $\mathrm{Glu}^{80}-\mathrm{Tyr}^{20}$ in relation to amount of receptors measured by ${ }^{125} \mathrm{I}$-insulin binding. Data are means \pm SEM of seven to ten separate experiments. Statistical significance of differences was assessed with the Wilcoxon signed rank test. ${ }^{\mathrm{a}} \mathrm{p}<0.05 ;{ }^{\mathrm{b}} \mathrm{p}<0.01$, vs no addition. ${ }^{\mathrm{c}} \mathrm{p}<0.05$ vs insulin alone at the indicated concentration. ND, Not determined

Lipolysis. When lipolysis was stimulated with $1 \mu \mathrm{mol} / 1$ isoprenaline (by 10-50-fold, data not shown) both insulin and $\mathrm{bpV}$ (pic) exerted equal, pronounced antilipolytic effects (Fig. 4A, B). The dose-response curve for the antilipolytic effect of $\mathrm{bpV}(\mathrm{pic})$ was shifted approximately fourfold to the right compared to the effect on glucose uptake, (Fig.4B vs Fig. 1), and the $\mathrm{EC}_{50}$ for the antilipolytic effect was $0.11 \pm 0.02$ $\mathrm{mmol} / \mathrm{l}(n=4)$. In contrast, the opposite relationship was found for these two effects of insulin, i. e., a higher sensitivity to the effect on lipolysis as compared to glucose uptake (for example Fig. 4A vs Fig. 2).

As shown in Figure 4A, the antilipolytic effect of insulin was completely blocked by the cilostamide derivative OPC 3911, a selective inhibitor of the low- $\mathrm{K}_{\mathrm{m}}$ cGMP-inhibitable phosphodiesterase (cGI-PDE) $[26,27]$. In contrast, this agent at a maximally effective concentration $(10 \mu \mathrm{mol} / \mathrm{l})$ did not affect the magnitude of the antilipolytic effect of $\mathrm{pV}$ (Fig.4B), whereas it tended to decrease cellular sensitivity to the $\mathrm{pV}$ compound. Inhibition of the so-called cAMP-specific phosphodiesterase (PDE) with Ro1724 [27] did not alter the antilipolytic effect of $\mathrm{pV}$ (Fig. 4B). Furthermore, lipolysis stimulated with the non-degradable cAMP analogue $\mathrm{N}^{6}$-monobutyryl cAMP [28] was not affected by insulin, whereas $\mathrm{bpV}(\mathrm{pic})$ at high concentrations $(5-10 \mathrm{mmol} / \mathrm{l})$ exerted a pronounced antilipolytic effect $(n=3$, $p<0.05$, data not shown).

Insulin receptor tyrosine kinase activity and protein tyrosine phosphorylation. Partially purified insulin receptors were obtained from human placenta in order to ensure sufficient quantities. The presence of insulin in the receptor preparation dose-dependently stimulated tyrosine kinase activity assessed by phosphate incorporation into $\mathrm{Glu}^{80}-\mathrm{Tyr}^{20}$, whereas $\mathrm{bpV}(\mathrm{pic})$ 


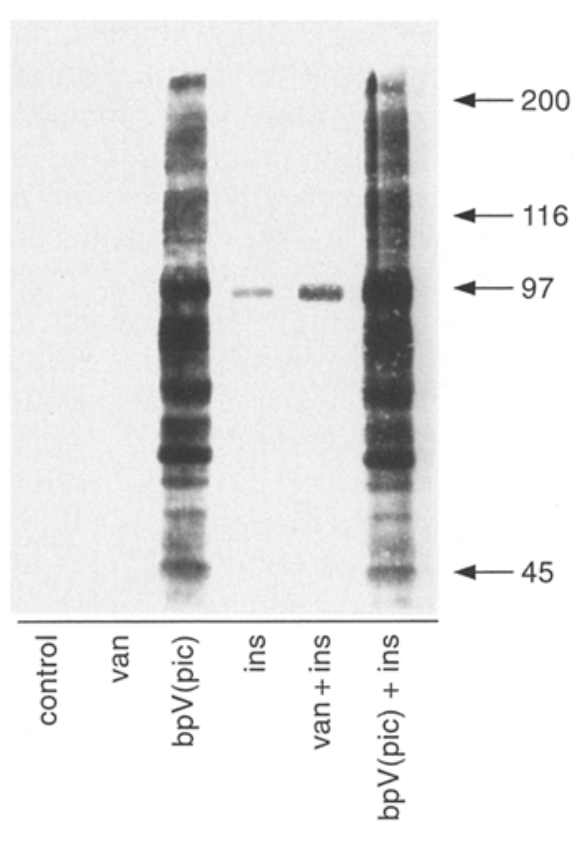

Fig. 5. Effect of insulin $(1000 \mu \mathrm{U} / \mathrm{ml}), \mathrm{bpV}($ pic $)(0.1 \mathrm{mmol} / 1)$ and vanadate $(4 \mathrm{mmol} / \mathrm{l})$ on tyrosine phosphorylation of lysates of human adipocytes. Intact cells were pre-incubated for 15 min at $37^{\circ} \mathrm{C}$ with or without vanadate and bpV(pic). During the final $10 \mathrm{~min}$ of the pre-incubation, insulin was added when indicated. Then, the cells were lysed and anti-phosphotyrosine immunoblots were performed as described in "Materials and Methods". Data are from one representative experiment of three. The indicated numbers refer to protein standards with different molecular weights $(\mathrm{kDa})$. Insulin receptor $\beta$-subunit approximately $97 \mathrm{kDa}$

alone, did not produce any effect (Table 1). However, when added together with insulin, bpV(pic) amplified the kinase activity. Vanadate $(1 \mathrm{mmol} / \mathrm{l})$ did not consistently influence basal or insulin-stimulated activity in this assay.

In situ tyrosine phosphorylation was assessed in lysates of human adipocytes. Insulin receptor $\beta$-subunit autophosphorylation of insulin-treated fat cells was amplified when $\mathrm{bpV}$ (pic) or vanadate was also present (Fig. 5). bpV(pic) alone, but not vanadate, enhanced insulin receptor $\beta$-subunit $(\sim 97 \mathrm{kDa})$ tyrosine phosphorylation, as well as tyrosine phosphorylation of several other proteins. In contrast, vanadate only amplified insulin-stimulated tyrosine phosphorylation, mainly at the insulin receptor $\beta$-subunit (Fig.5).

\section{Discussion}

Vanadate and $\mathrm{H}_{2} \mathrm{O}_{2}$ in combination act synergistically to produce a powerful insulin-like effect. This is attributed to $\mathrm{pV}$ compounds formed by the two agents [15]. However, aqueous $\mathrm{pV}$ solutions are unstable [15] and, thus, unsuitable as therapeutic agents in insulin-resistant states. This study investigated the insu- lin-like action in human adipocytes of a well-characterized stable $\mathrm{pV}$ compound. The data show that this agent, bpV(pic), is at least as effective as the previously studied combination of vanadate and $\mathrm{H}_{2} \mathrm{O}_{2}$ [19]. The effect of $\mathrm{bpV}$ (pic) on glucose uptake was nearly as pronounced as the effect of insulin itself, whereas the antilipolytic response to these two agents did not differ.

With glucose uptake a biphasic dose-response curve for $b p V$ (pic) was found. The range of effective concentrations was, however, much wider than for the combination of vanadate and $\mathrm{H}_{2} \mathrm{O}_{2}$ (approximately three orders of magnitude compared to one, respectively [19]. It is not clear why glucose uptake returns towards basal levels at high $\mathrm{pV}$ concentrations. Previously, we speculated that a competitive interaction with vanadate formed by ligand dissociation from $\mathrm{pV}$ solutions may be involved [19]. However, bpV(pic) is stable and not expected to decompose. This was also supported by the finding of a biphasic curve even when a much shorter incubation period was used; total time 35 instead of 75 min (data not shown). Furthermore, another $\mathrm{pV}$ compound, bpV(phen), which is even more stable than bpV(pic) $\left(\mathrm{t}_{1 / 2}\right.$ in solution $10 \mathrm{vs} 8.5$ days, respectively [18]) also displayed a biphasic effect on glucose uptake (data not shown). An alternative explanation for biphasic dose-response curves is that $\mathrm{pV}$ complexes, while shown to be specific phosphotyrosine phosphatase inhibitors $[16,18]$ at high concentrations may also inhibit serine/threonine phosphatases [18]. Such an effect of $\mathrm{pV}$ may lead to enhanced serine/threonine phosphorylation of the insulin receptor itself, the GLUT 4 glucose transporter and/or protein kinase A, leading to a decreased rate of glucose transport. In contrast, the antilipolytic action of $b p V(p i c)$ was not biphasic. This may also be explained by an increased serine phosphorylation and subsequent activation of the cGMP inhibitable phosphodiesterase leading to an inhibition of lipolysis $[29,30]$. However, further studies are clearly required to corroborate this hypothesis.

Insulin sensitivity, assessed as insulin-stimulated glucose uptake, was not affected by submaximal $\mathrm{bpV}(\mathrm{pic})$ concentrations. This differs from results of vanadate treatment in rat adipocytes [25]. This discrepancy may, at least partly, be due to the lack of effect of $\mathrm{bpV}(\mathrm{pic})$ on insulin binding in human adipocytes. Vanadate, on the other hand, enhances insulin binding and insulin sensitivity in rat adipocytes [25, 31]. Thus, the present results suggest that, in human adipocytes, $\mathrm{pV}$ compounds exert their effects mainly at the post-binding level.

The inhibitory action of vanadate on $b p V($ pic)stimulated glucose uptake is likely to be due to a competition between vanadate and $\mathrm{bpV}$ (pic) at critical post-receptor sites. Cytosolic tyrosine kinases may be involved, since vanadate has been reported 
to exert its insulin-like effects in rat fat cells via such a kinase [32]. Other possible explanations for the inhibitory effect of vanadate on bpV(pic) action include competition for a common transmembrane transport mechanism (B.I. Posner et al., unpublished data) leading to a decrease in cellular uptake of $\mathrm{bpV}(\mathrm{pic})$ as well as an inhibitory effect of the major intracellular form of vanadate, vanadyl, on insulin receptor kinase activity [33].

The antilipolytic effect of $\mathrm{bpV}(\mathrm{pic})$ displayed differences from that of insulin. First, the dose-response curve for $b p V(p i c)$ was shifted approximately fourfold to the right compared to its effect on glucose uptake. Insulin displayed the opposite relationship, i.e., a greater sensitivity for antilipolysis than for glucose uptake. Second, the selective inhibitor of the cGIPDE, OPC 3911, impaired the sensitivity but not the responsiveness to the antilipolytic action of $\mathrm{bpV}(\mathrm{pic})$. In contrast, insulin's antilipolytic effect was completely abolished, which is consistent with previous findings [29, 34] and documents the key role of cGIPDE activation for the antilipolytic effect of insulin in fat cells. Taken together, these findings indicate that partially divergent pathways are involved in the actions of insulin and $\mathrm{bpV}$ (pic) on lipolysis. The effect of insulin to stimulate cGI-PDE leads to an enhanced degradation of intracellular cAMP $[29,34]$ which, in turn, reduces the rate of lipolysis. Although activation of cGI-PDE also seems to be one important mechanism for the effect of $\mathrm{bpV}$ (pic), additional mechanisms must be involved. This is also supported by the finding that lipolysis stimulated by $\mathrm{N}^{6}$ mbcAMP, a cAMP-analogue which is resistant to degradation by cGI-PDE $[28,34]$, was inhibited by high concentrations of $\mathrm{bpV}(\mathrm{pic})$ but not by insulin. This is at variance with our previous work [19] in which we found no effect of the aqueous $\mathrm{pV}$ solution on $\mathrm{N}^{6}$-mbcAMP-stimulated lipolysis. However, it is not clear which concentrations of $\mathrm{pV}$ were attained in that study but they were probably much lower than those presently employed. In harmony with our present findings, it has previously been reported that vanadate can stimulate cGI-PDE through activation of tyrosine kinases and protein kinase $\mathrm{C}$ in a manner different from that of insulin [35].

The basic mechanisms for $\mathrm{pV}$ action are, as discussed above, not fully established. The possibility that the peroxide component per se plays a critical role should be taken into account. In addition, previous work has shown that insulin can activate an $\mathrm{H}_{2} \mathrm{O}_{2}$-generating system, and that $\mathrm{H}_{2} \mathrm{O}_{2}$ is capable of producing insulin-like effects in human adipocytes [14]. Vanadate and, thus, also $\mathrm{pV}$ compounds could possibly act in a similar manner by activating NADH oxidase which promotes $\mathrm{H}_{2} \mathrm{O}_{2}$ formation $[13,36]$. The present data, however, clearly argue against $\mathrm{H}_{2} \mathrm{O}_{2}$ as the sole mediator for the action of $\mathrm{bpV}$ (pic). The effect of $\mathrm{H}_{2} \mathrm{O}_{2}$ on glucose uptake was not as marked as that of $\mathrm{bpV}$ (pic), and, furthermore, much higher concentrations $(-100$-fold $)$ were needed to exert a maximal effect. A more likely mechanism for the action of $b p V$ (pic) on human fat cells is its ability to enhance insulin receptor tyrosine kinase activity [15-18]. Previous work has shown that this is not due to a direct effect of $\mathrm{pV}$ on the insulin receptor [37] but rather to its ability to inhibit PTP associated in situ with the insulin receptor $[17,18]$. This results in receptor autophosphorylation and activation, albeit at a slower rate than that seen following insulin administration $[18,37]$. The present data support this concept since $\mathrm{bpV}$ (pic) alone had no significant effect on partially purified insulin receptors. Its ability to augment the effect of insulin may reflect the presence of some PTP activity in the preparations of partially purified insulin receptors used in this study. The effect of $b p V(p i c)$ in intact cells to augment insulin receptor $\beta$-subunit phosphorylation as well as tyrosine phosphorylation of several other proteins in situ, even in the absence of insulin, probably reflects the presence of PTPs in the intact cell which play a major role in the regulation of the receptor phosphorylation state [37]. This may also suggest an ongoing, constitutive phosphorylation/dephosphorylation process in intact cells, as opposed to the partially purified receptor preparation where insulin may be required to induce a significant receptor phosphorylation. These findings are also consistent with previous results with vanadate as well as $\mathrm{pV}$ in rat adipocytes $[15,16$, $25,37]$. The inability of bpV(pic) as well as vanadate (U. Smith, unpublished data) to alter insulin sensitivity in human fat cells with respect to glucose uptake indicates that under the employed conditions an enhanced insulin-stimulated receptor autophosphorylation and kinase activity does not further amplify the insulin signal. This implies a large spare kinase activity of the insulin receptor.

Although the mechanisms involved are not fully established, it is clear that $\mathrm{bpV}$ (pic), a stable $\mathrm{pV}$ compound, is a powerful insulin-mimic in human fat cells. Ongoing in vivo studies indicate that this agent is effective in tissues other than fat, e.g., liver and skeletal muscle (J.-F. Yale et al., unpublished data). Moreover, $\mathrm{pV}$ administered i. p. was recently shown to produce a rapid insulin-like response in diabetic rats in vivo [38]. Further investigations are warranted to elucidate the mechanisms underlying the metabolic effects of $\mathrm{pV}$ compounds and also to assess the efficacy of these agents in human and animal states of insulin resistance.

Acknowledgements. We would like to thank Ms. B. KarlssonSvalstedt and Ms. A. Johansson for skillful technical assistance, Ms. A.-L. Dahlgren for the careful preparation of the manuscript and Dr. J. Ng for providing the peroxovanadium compounds. Financial support was given by the Swedish Medical Research Council (project B-3506), IngaBritt and Arne Lundberg Foundation, King Gustaf V and Queen Victoria Founda- 
tion, Swedish Diabetes Association, Göteborg Diabetes Association, Swedish Society of Medicine, Göteborg Medical Society, Novo-Nordisk Foundation, Tore Nilson Foundation, and Sahlgrenska Hospital Funds.

\section{References}

1. Shechter Y (1990) Insulin-mimetic effects of vanadate: possible implications for future treatment of diabetes. Diabetes $39: 1-5$

2. Nechay BR (1984) Mechanisms of action of vanadium. Ann Rev Pharmacol 24: 501-524

3. Tolman EL, Barris E, Burns M, Pansini A, Partridge R (1979) Effects of vanadium on glucose metabolism in vivo. Life Sci 25: 1159-1164

4. Shechter Y, Karlish SJD (1980) The insulin-mimetic effects of vanadate in isolated rat adipocytes. Nature (London) 284: 556-558

5. Mooney RA, Bordwell KL, Luhowskyj S, Casnellie JE (1989) The insulin-like effect of vanadate on lipolysis in rat adipocytes is not accompanied by an insulin-like effect on tyrosine phosphorylation. Endocrinology 124: 422-429

6. Tamura S, Brown TA, Wipple JH et al (1984) A novel mechanism for the insulin-like effect of vanadate on glycogen synthase in rat adipocytes. J Biol Chem. 259: 6650--6658

7. Heyliger CE, Tahiliant AG, McNeill JH (1985) Effect of vanadate on elevated blood glucose and depressed cardiac performance of diabetic rats. Science 227: 1474-1476

8. Blondel O, Bailbe D, Portha B (1989) In vivo insulin resistance in streptozotocin-diabetic rats - evidence for reversal following oral vanadate treatment. Diabetologia 32: 185190

9. Bernier M, Laird DM, Lane MD (1988) Effect of vanadate on the cellular accumulation of pp15, an apparent product of insulin receptor tyrosine kinase action. I Biol Chem 263: $13626-13634$

10. Swarup G, Speeg KV Jr, Cohen S, Garbers DL (1982) Phosphotyrosyl-protein phosphatase of TCRC-2cells. J Biol Chem 257: 7298-7301

11. Strout HV, Vicario P, Saperstein R, Slater EE (1989) The insulin-mimetic effect of vanadate is not correlated with insulin receptor tyrosine kinase activity nor phosphorylation in mouse diaphragm in vivo. Endocrinology 124: 1918-1924

12. Czech MP, Lawrence JC Jr, Lynn WS (1974) Hexose transport in isolated brown fat cells. J Biol Chem 249: 5421-5427

13. Muchmore DB, Little SA, deHaen C (1982) Counterregulatory control of intracellular hydrogen peroxide production by insulin and lipolytic hormones in isolated rat epididymal fat cells. A role of free fatty acids. Biochemistry 21: $3886-3892$

14. Krieger-Brauer HI, Kather H (1992) Human fat cells possess a plasma membrane-bound $\mathrm{H}_{2} \mathrm{O}_{2}$-generating system that is activated by insulin via a mechanism bypassing the receptor kinase. J Clin Invest 89: 1006-1013

15. Kadota S, Fantus IG, Deragon G, Guyda HJ, Hersh B, Posner BI (1987) Peroxide(s) of vanadium. a novel and potent insulin-mimetic agent which activates the insulin receptor kinase. Biochem Biophys Res Commun 147: 259-266

16. Kadota S, Fantus IG, Deragon G, Guyda HJ, Posner BI (1987) Stimulation of insulin-like growth factor II receptor binding and insulin receptor kinase activity in rat adipocytes. Effects of vanadate and $\mathrm{H}_{2} \mathrm{O}_{2}$. J Biol Chem 262: $8252-8256$

17. Faure R, Baquiran G, Bergeron JJM, Posner BI (1992) The dephosphorylation of insulin and epidermal growth factor receptors. Role of endosome-associated phosphotyrosine phosphatase(s). J Biol Chem 267: 11215-11221

18. Posner BI, Faure R, Burgess JW et al. (1994) Peroxovanadium compounds. A new class of potent phosphotyrosine phosphatase inhibitors which are insulin mimicks. J Biol Chem 269: 4596-4604

19. Lönnroth P, Eriksson JW, Posner BI, Smith U (1993) Peroxovanadate but not vanadate exerts insulin-like effects in human adipocytes. Diabetologia 36: 113-116

20. Smith U, Sjöström L, Björntorp P (1972) Comparison of two methods for determining human adipose cell size. J Lipid Res 13: 822-824

21. Kashiwagi A, Verso MA, Andrews J, Vasques B, Reaven G, Foley JE (1983) In vitro insulin resistance of human adipocytes isolated from subjects with noninsulin-dependent diabetes mellitus. J Clin Invest 72: 1246-1252

22. Bradley DC, Kaslow HR (1989) Radiometric assays for glycerol, glucose, and glycogen. Anal Biochem 180: 11-16

23. Harrison LC, Itin A (1980) Purification of the insulin receptor from human placenta by chromatography on immobilized wheat germ lectin and receptor antibody. J Biol Chem 255: 12066-12072

24. Zick Y, Kasuga M, Kahn CR, Roth J (1983) Characterization of insulin-mediated phosphorylation of the insulin receptor in a cell-free system. J Biol Chem 258: 75-80

25. Eriksson JW, Lönnroth P, Smith U (1992) Vanadate increases cell surface insulin binding and improves insulin sensitivity in both normal and insulin-resistant rat adipocytes. Diabetologia 35: 510-516

26. Degerman E, Belfrage $P$ (1987) Purification of the putative hormone-sensitive cyclic AMP phosphodiesterase from rat adipose tissue using a derivative of cilostamide as a novel affinity ligand. J Biol Chem 262: 5797-5807

27. Manganiello V, Degerman E, Elks M (1988) Selective inhibitors of specific phosphodiesterases in intact adipocytes. Methods Enzymol 154: 504-520

28. Beebe SJ, Holloway R, Rannels SR, Corbin JD (1984) Two classes of cAMP analogs which are selective for the two different cAMP-binding sites of type-II protein kinase demonstrate synergism when added together to intact adipocytes. J Biol Chem 259: 3539-3547

29. Degerman E, Smith CJ, Tornqvist H, Vasta V, Belfrage P, Manganellio VC (1990) Evidence that insulin and isoprenaline activate the cGMP inhibited low- $K_{m}$ cAMPphosphodiesterase in rat fat cells by phosphorylation. Proc Natl Acad Sci USA 87: 533-537

30. Shibata H, Robinson FW, Soderling TR, Kono T (1991) Effects of okadaic acid on insulin-sensitive cAMP phosphodiesterase in rat adipocytes. J Biol Chem 266: 17948-17953

31. Fantus IG, Ahmad F, Deragon G (1990) Vanadate augments insulin binding and prolongs insulin action in rat adipocytes. Endocrinology 127: 2716-2725

32. Shisheva A, Shechter Y (1993) Role of cytosolic tyrosine kinase in mediating insulin-like actions of vanadate in rat adipocytes. J Biol Chem 268: 6463-6469

33. Elberg G, Li J, Shechter Y (1994) Vanadium activates or inhibits receptor and non-receptor protein tyrosine kinases in cell-free experiments depending on its oxidation state. Possible role of endogenous vanadium in controlling cellular protein tyrosine kinase activity. J Biol Chem 269: 95219527

34. Lönnroth P, Smith U (1986) The antilipolytic effect of insulin in human adipocytes requires activation of the phosphodiesterase. Biochem Biophys Res Commun 141: 11571161

35. Ueki H, Okuhama R, Sera M, Inoue T, Tominaga N, Morita $T$ (1992) Stimulatory effect of vanadate on $3^{\prime}, 5^{\prime}$-cyclic 
guanosine monophosphate-inhibited low Michaelis-Menten constant $3{ }^{\prime}, 5^{\prime}$-cyclic adenosine monophosphate phosphodiesterase activity in isolated rat fat pads. Endocrinology 131: 441-446

36. Maj JM, de Haen C (1979) Insulin-stimulated intracellular hydrogen peroxide production in rat epididymal fat cells. J Biol Chem 254: 2214-2220
37. Fantus IG, Kadota S, Deragon G, Foster B, Posner BI (1989) Pervanadate [peroxide(s) of vanadate] mimics insulin action in rat adipocytes via activation of the insulin receptor tyrosine kinase. Biochemistry 28: 8864-8871

38. Shisheva A, Ikonomov O, Shechter Y (1994) The protein tyrosine phosphatase inhibitor, pervanadate, is a powerful antidiabetic agent in streptozotocin-treated diabetic rats. Endocrinology 134: 507-510 